\title{
Meaning Making and Death in a Secular Society: A Dutch Survey Study
}

\author{
Joanna Wojtkowiak, ${ }^{\text {a) }}$ Bastiaan T. Rutjens, ${ }^{\text {b) }}$ and Eric Venbrux ${ }^{\text {a) }}$ \\ a) Radboud University Nijmegen, The Netherlands \\ E-mail: J.Wojtkowiak@rs.ru.nl \\ b) University of Amsterdam, The Netherlands
}

Received: 23 February 2010; revised: 23 July 2010; accepted: 9 August 2010

\begin{abstract}
This article focuses on the relation between death and religion in a secularized society. In the Netherlands, traditional religious membership has declined significantly together with traditional belief systems. This study investigates the relation between the experience of death and religious affiliation (unaffiliated, Catholic, and Protestant) in relation to meaning making. Parts of a nationwide survey study $(\mathrm{n}=1212)$ are analyzed in order to investigate different forms of meaning making (Christian meaning, personal meaning, and denial of meaning). The results show that the experience of the death of a loved one is related to personal meaning giving only for Protestant participants. Moreover, religiously unaffiliated, Catholics and Protestants differ significantly in different ways of meaning making. In the discussions the authors focus on the different effects of different religious groups in the context of secular society.
\end{abstract}

\section{Keywords}

meaning making; death; secular society; religious affiliation; The Netherlands

Experiencing the death of a loved one is one of the most difficult moments in life. Death asks for meaning or sense in order to 'move on' or to be able to deal with the fact that the loved one is gone. Meaning making can be defined as a process that has beneficial results on attitudes towards life and as a search for an explanation for loss (Davis, Nolen-Hoeksma $\&$ Larson, 1998). Traditional religion is one of the most obvious ways to give meaning to death, as death is understood as a passage to another life within a given belief system. Different religions offer various ways of dealing with and meaning making of death in the form of beliefs, rituals, or behavioural guidance. The relation between 
death and religion has been the subject of investigation since the early days of social sciences (James, 1978: 1902; Malinowski, 1925; Tylor, 1871). William James writes in his classical work on religious experiences:" death finally runs the robustest of us down [...]". And here religion comes to our rescue and takes our fate into her hands" (William James, 1902, p. 63). In contemporary secular societies, the role of traditional religiosity has declined significantly. In this study we investigate the relation between death and religion in a secularized context.

Religious beliefs can serve multiple psychological functions (Pargament, 2002). One of these functions is reducing existential threat (Veil et al. 2010), and experimental research on death thoughts and religious membership has shown that religiosity can indeed protect people against mortality concerns (e.g., Friedman \& Rholes, 2008; Norenzayan, Dar-Nimrod, Hansen, \& Proulx, 2009). However, within survey studies, the relation between meaning giving and religion remains complex (Falkenhain \& Handal, 2003; Park, $2005,2010)$. Studies on death attitudes and the role of religion show equivocal, sometimes controversial results. Another difficulty regarding the study of the relation between religion and death is related to the role of religion in contemporary Western society.

Religiosity and more specifically beliefs in life after death have become quite diverse in secular societies (Burris \& Bailey, 2009; Halman \& Draulans, 2006; Verweij, Ester \& Nauta, 1997). Due to this diversity, the bereaved display different strategies in coping with the death of a loved one (Benore $\&$ Park, 2004; Stroebe, 2004; Unruh, 1983). Some of these strategies are religious, such as praying for the soul of the deceased, but others are secular, such as telling stories about the deceased, keeping material objects that belonged to the deceased or doing activities one used to do together (Stroebe, 2004; Unruh, 1983). In general, in many European countries traditional church membership has declined significantly over the last decades (Halman $\&$ Draulans, 2006). Nevertheless, there remains a significant group of people that can neither be described as a church member2, nor as outspokenly unreligious (Storm, 2009).

The literature on death in the Netherlands indicates that although church membership is low (e.g., Achterberg et al., 2009; Halman \& Daulans, 2006), dealing with death ranges from secular to religious and spiritual interpretations (Becker, 2006; Bernts, Dekker, \& De Hart, 2007; Wojtkowiak \& Venbrux, 2009). Research on funeral practices in the Netherlands has shown that Catholic funerals are strongly personalized, leaving space for the bereaved to express their personal relationship with the deceased (Quartier, 2007). The 
Catholic tradition is known for its ritual richness in dealing with death. On the other hand, Protestant approaches towards death, although also influenced by individualism, are characterized more by tradition (Lucke, Gilbert $\&$ Barrett, 2006). For example, Protestants view their religious identity to be primarily based on the relationship with God and less on the social aspects of the religious community, which is also expressed in their ways of dealing with death (Cohen \& Hall, 2009). Moreover, Catholics seem to show more mourning concerns than Protestants, which might be due to the fact that within Catholicism a more exuberant mourning tradition is practiced (Cohen $\&$ Hall, 2009). A study on religious affiliation and coping with stress in the case of organ transplantation has shown that for Protestants' religious coping is more effective (Tix \& Frazier, 1998). Other research showed significant differences between Catholics and Protestants in religious coping in life stress events, with Protestants relying much more on religious convictions (Park, Cohen \& Herb, 1990).

In a recent literature review on meaning making it is shown that after a stressful event, such as death, people tend to adjust their global meaning system (Park, 2010). Examples of such adjustment are: changing beliefs or goals, reconstructing the own identity, perceptions of growth or feeling that sense has been 'made'. Moreover, it is shown that the majority of people who went through a crisis situation (e.g. death, disease) asked or searched for meaning. For example, a study on complicated grief and meaning revealed that $89 \%$ of the bereaved participants were noted to have actively searched for meaning (Tolstikova, Fleming \& Chartier, 2005). Bereavement is often considered a process, a psychosocial transition, suggesting there is some sort of change after experiencing death (Parkes 1971, 1988). Some authors describe different phases of bereavement on an individual and a social level, referring to the experience of different emotions, from shock to depression, but also to the change of social structures, for example through the participation in the funeral ritual (Turner, 1969; Yorick, 1973). Therefore, the experience of a death in the own environment might lead to changes in attitudes towards life and death. The literature shows that bereavement is a process where people are reflecting on different aspects of life, which are related to people's meaning making system.

But how is religious affiliation related to dealing with death in terms of meaning making in a secularized society? Does death 'run the robustest of us down' (James, 1902, p. 63) or have people found alternative ways of dealing with the death of a loved one? In this study we investigate whether religious background and the experience of the death of a loved one are related to 
meaning making of life and death. The term 'meaning giving' refers to a wide range of beliefs, goals, well being, and satisfaction, and will in the current study be operationalized in three dimensions: Christian meaning, personal meaning, and denial of meaning. The research question is: how is religious affiliation and the experience of a death of a loved one related to meaning making in the Netherlands? Is there a relation between meaning making and the experience of the death of a loved one? Previous literature has shown that there are differences between religious groups, such as Catholics and Protestants, in dealing with death (e.g. Cohen \& Hall, 2009; Lucke et al., 2006, Park et al., 1990). We therefore expect different results in meaning making and the experience of death between different religious affiliations (Catholics, Protestants and unaffiliated). As this study was conducted in a strongly secularized society, the Netherlands, we expect significant differences between those who are or are not a member of a church in different ways of dealing with death. Personal meaning making, as well as denial of meaning, is expected to be found mostly within the religiously unaffiliated group. Within religious groups, such as Catholics and Protestants, Christian meaning making is expected to play a larger role. Based on previous literature, Catholics are expected to find more meaning in a personal way than Protestants, as Protestants have been shown to have a stronger religious identity based on their faith and tradition. The experience of the death of a loved one is expected to be related to meaning making in the following way: within the different religious groups, the meaning making that is generally the most strongly represented will be further relied upon when a death is experienced. In other words, the unaffiliated will exhibit stronger personal meaning making or denial of meaning in relation to death, whereas Protestants and Catholics will show increased Christian meaning. For Catholics, however, based on previous literature on dealing with death, we might also expect an increase in personal meaning making, as a result of general personalization of Catholic rituals and dealings with death.

\section{Method}

The current data are derived from a nationwide representative Dutch survey on socio-cultural developments in the Netherlands (SOCON), conducted in 2005 by researchers from the Faculty of Social Sciences at Radbaud University Nijmegen. This long-term survey consists of different questions regarding various social and cultural issues in the Netherlands and has been conducted 
since 1979 (Felling, 2004). The respondents $(N=1212)$ were selected by their postal code. $47 \%$ were male and $53 \%$ were female. Mean age was 50 years $(S D=14)$, with a range from 20 to 72 years. $60 \%$ of the participants did not consider themselves members of a church, $20 \%$ were said to be Catholic, 15 $\%$ Protestant and $5 \%$ other. $^{1}$

In the section 'Innovations in Mortuary Rites', participants were asked if they had experienced the death of a loved one. Of the participants, $46 \%$ were said to have lost a significant person. A principal component analysis was conducted on the items that were used to operationalize meaning of life and death, which resulted in three factors (Cronbach's alphas in parentheses):

1) personal meaning of life and death (.70): you have to deal with grief and sorrow by yourself and 'the meaning of life is the one that you give to it';

2) Christian meaning of life and death (.88), such as 'death is a passage to another life' and 'death has only meaning when you believe in God';

3) denial of meaning of life and death (.74) that consisted of statements such as 'death has no meaning at all' and 'after death everything is over' (see Table 1 and Fig. 1).

The first factor 'personal meaning' is based on personal convictions of giving meaning to life and death by you. The second factor 'Christian meaning' represents a traditional religious frame (in this case Christian), by referring to God and an afterlife as sources of meaning. The fact that this factor is restricted to Christian meaning was not of influence on the analysis, as other religious groups, such as Muslims or Buddhists were underrepresented in the sample and were not included in the current analyses. The third factor 'denial of meaning' represents the attitude that there is no perceived meaning to life, death, and suffering. The answers ranked from 1 (totally disagree) to 5 (totally agree). The grand means were: personal meaning $M=4.0, S D=0.6$, Christian meaning $M=2.5, S D=0.7$, denial of meaning $M=2.4, S D=0.7$.

\footnotetext{
1) The Muslim population is underrepresented in this sample: approximately $1.6 \%$. This is lower than the average Dutch population (about $5 \%$ ). Therefore participants describing themselves as Muslim were not included in the analysis. The number of respondents from other religious affiliations, such as Buddhists, Hindus or Jews, was too small to be included in the analysis.
} 


\section{Results}

A 2 (deceased loved one yes vs. deceased loved one yes no) x 3 (denomination: religiously unaffiliated vs. Catholic vs. Protestant) ANOVA was conducted on meaning making of life and death (personal, Christian and denial). First of all, there was a significant main effect of death of a loved one on personal meaning making $F(1,993)=10.911, p=.001$. Participants who have lost a loved one scored lower on personal meaning $(M=3.8, S D=.027)$ than participants who have not $(M=4.0, S D=0.32)$. There was no significant effect of death of a loved one on Christian meaning $(p=.489)$ and not on denial of meaning $(p=.286)$.

Next, we found a significant main effect of denomination on all three forms of meaning making (see Table 1): personal, $F(2,994)=51,362, p=.000$, Christian, $F(2,994)=60.605, p=.000$ and denial, $F(2,994)=204.958, p=$ .000 . The means in Fig. 1 show that personal meaning was highest within all groups (Unaffiliated $M=4.1, S D=0.02$, Catholic $M=4.0, S D=0.04$, Protestant $M=3.6, S D=0.04$ ). Second came the means for Christian meaning making (Unaffiliated $M=2.1, S D=0.03$, Catholic $M=2.7, S D=0.06$, Protestant $M=3.4, S D=0.06$ ) and the lowest means were found on denial of meaning (Unaffiliated $M=2.5, S D=0.03$, Catholic $M=2.5, S D=0.05$, Protestant $M=1.9, S D=0.05)$. Unaffiliated respondents scored higher on denial of meaning than on Christian meaning.

Moreover, we found a significant interaction of death of a loved one and denomination on personal meaning, $F(2,994)=7.016 p=.001$. The means are shown in Table 1 and reveal that Protestants who had lost a loved one generally scored lower on personal meaning, suggesting that experiencing death leads to less effort in searching for meaning in a personal way (Protestant lost loved one $M=3.4, S D=0.07$, Protestant not lost loved one $M=$

Table 1. Means and standard deviations of meaning (Personal, Christian, Denial) by religious affiliation

\begin{tabular}{lccc}
\hline & Unaffiliated & Catholic & Protestant \\
\hline Personal & $4.1^{\mathrm{a}}(.02)$ & $4.0^{\mathrm{a}}(.04)$ & $3.6(.04)$ \\
Christian & $2.1(.03)$ & $2.7(.06)$ & $3.4(.06)$ \\
Denial & $2.5(.03)$ & $2.3(.05)$ & $1.9(.05)$ \\
\hline
\end{tabular}

Note. Means differ significantly across rows and columns $(p<.000)$, with exception those with superscripts $(p=.075)$, SD's in parentheses. 


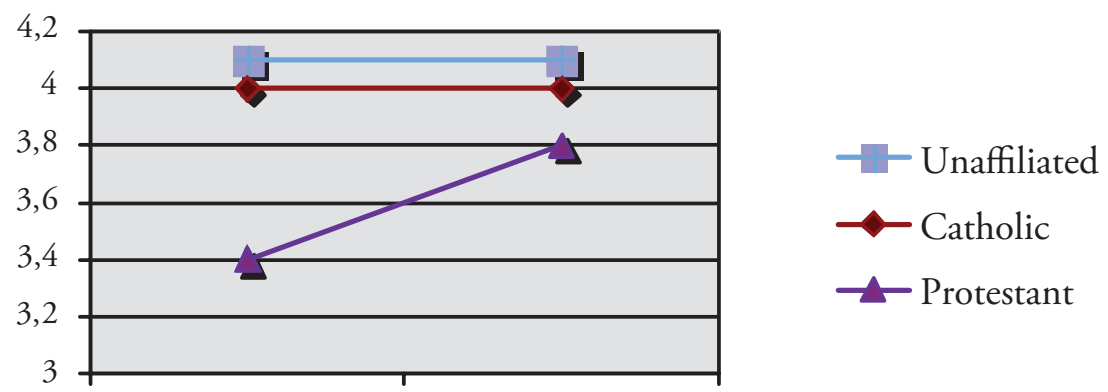

Death yes

Death no

Fig. 1. Interaction between death of a loved one and religious affiliation on personal meaning making.

$3.8, S D=0.06)$. Catholics and religious unaffiliated respondents did not differ significantly on personal meaning between those who had lost a loved one or not (Catholic lost loved one $M=4.0, S D=0.05$, Catholic not lost loved one $M=4.0, S D=0.06$; unaffiliated lost loved one: $M=4.1, S D=0.03$, Unaffiliated not lost loved one: $M=4.1, S D=0.03)$. More in general, Catholics and religiously unaffiliated scored higher on personal meaning than Protestants. There was no significant interaction effect of death of a loved one and religious affiliation on Christian meaning making $(p=.86)$ and not on denial of meaning $(p=.277)$.

\section{Discussion}

The current research investigated the relation between religious affiliation and the experience of death on meaning making. The hypothesis that different religious groups have different meaning making strategies in relation to death (unaffiliated: stronger personal meaning and denial of meaning; Protestants and Catholics: stronger Christian meaning) was only partially supported. We found a significant interaction between death of a loved one and religious affiliation for personal meaning making only. The results show that Protestants who had lost a loved one scored lower on personal meaning than Protestants who had not lost a loved one. This finding suggests that Protestants derive meaning less from an individual perspective when having experienced the death of a loved one. Catholics and religiously unaffiliated respondents who had experienced the death of a loved one did not differ in personal meaning, 
and generally scored higher on personal meaning than Protestants. This finding can be explained by the finding that Protestants build their religious identity to a larger part on their relationship with God and their faith (Cohan \& Hall, 2009; Park, Cohen \& Herb, 1990; Tix \& Frazier, 1998). This is also reflected by Protestants scoring highest on Christian meaning making.

Christian meaning and denial of meaning were not related to the experience of death, but to religious affiliation only. These two sources of meaning are both based on a conviction, that either includes the belief in an afterlife and higher power (Christian) or an explicit disbelief in meaning of life and death, which is perhaps why both concepts are not related to the experience of death. Personal meaning making in that sense might be described as more 'neutral' and applicable both within a religious identity as well as within a secular identity. This is underlined by the fact that personal meaning making was represented the highest within all groups. Personal meaning making does not presuppose a deeper conviction or clear interpretation of death, but is cantered on giving individual meaning to death. This type of meaning giving seems to fit quite well within an individualized secular society such as the Netherlands.

More generally, the grand means show that personal meaning giving was highest within all religious groups, compared to the other two forms of meaning giving. This shows that in general Dutch society is quite secularized concerning meaning making; not only regarding the majority of religiously unaffiliated, who prefer a personal and even denial of meaning above Christian meaning, but also those who consider themselves as Catholic tend to rely more on personal meaning than on Christian meaning. Catholics did not differ much from the religiously unaffiliated in the different dimensions of meaning giving, which is in line with previous research on the personalization of Catholic funerals in the Netherlands (Quartier, 2007). Protestant participants differed the most from the other groups, suggesting that Protestants are relying more on their religious faith, which also fits with previous research (Cohan \& Hall, 2009; Lucke, Gilbert \& Barrey, 2006; Park, Cohen \& Herb, 1990; Tix \& Frazier, 1998).

A limitation of this study is that religious minorities, for example Muslims, are underrepresented. Moreover, the meaning making dimensions were restricted to Christian meaning making, which does not allow generalizing the results to other religious groups that are represented in the Netherlands, such as Jews, Buddhists or Hindus. 
The relation between death and religion in the Netherlands has changed in terms of declined church membership, but this study shows that, within Dutch churches, there is also room for personal meaning making. There are still variations between religious affiliations in the amount of Christian interpretation of life and death between Protestants and Catholics. Protestants generally rely more on their Christian tradition than Catholics, and after the experience of death personal meaning giving decreases. This study shows that the relation between death and religion needs more attention towards varieties between religious groups and a stronger focus on secular, personal ways of meaning giving.

\section{References}

Bänziger, S., Janssen, J., \& Scheepers, P. (2008). Praying in a secularized society: An empirical study of praying practices and varieties. The International Journal for the Psychology of Religion, 18(3), 256-265.

Becker, J. (2006). Nederland en de secularisatie. Enige trends in gegevens met betrekking tot levensbeschouwing (The Netherlands and secularization: Some trends pertaining to outlook on life). Religie \& Samenleving, 1(1), 5-25.

Benore, E. R., \& Park, C. L. (2004). Death-specific religious beliefs and bereavement: belief in an afterlife and continued attachment. The International Journal for the Psychology of Religion, 14(1), 1-22.

Bernts, T., Dekker, G., \& Hart, de, J. (2007). God in Nederland, 1996-2006. Kampen: Ten Have.

Burris, C. T., \& Baily, K. (2009). What lies beyond: Theory and measurement of afterdeath beliefs. The International Journal for the Psychology of Religion, 19(3), 173-186.

Cohan, A. B., \& Hall, D. E. (2009). Existential beliefs, social satisfaction, and well-being among Catholic, Jewish, and Protestant older adults. The International Journal for the Psychology of Religion, 19(1), 39-54.

Davis, C. G., Nolen-Hoeksma, S., \& Larson, J. (1998). Making sense of loss and benefiting from the experience: two construals of meaning. Journal of Personality and Social Psychology, 75(2), 561-574.

Falkenhain, M., \& Handal, P. J. (2003). Religion, death attitudes, and belief in afterlife in the elderly: understanding the relationships. Journal of Religion and Health, 42(1), 67-76.

Felling, A. (2004). Het proces van individualisering in Nederland: een kwarteenw sociaal-culturele ontwikkeling. (The process of individualization in the Netherlands: a quarter century of socio-cultural development.) Farewell speech professor Felling on $8^{\text {th }}$ January 2004, Radboud University Nijmegen. 
Friedman, M., \& Rholes, W. S. (2008). Religious fundamentalism and terror management. The International Journal for the Psychology of Religion, 18(1), 36-52. Journal for the Scientific Study of Religion, 47(4), 585-598.

Halman, L., \& Draulans, V. (2006). How secular is Europe? The British Journal of Sociology, 57(2), 263-288.

Haraldsson, E. (2006). Popular psychology, belief in life after death and reincarnation in the Nordic countries, Western and Eastern Europe. Nordic Psychology, 58(2), 171-180.

James, W. (1978: 1902). The Varieties of Religious Experience. New York: Image Books.

Keenan, W. (2002). Post-secular sociology: effusions of religion in late modern settings. European Journal of Social Theory, 5(2), 279-290.

Lucke, G., Gilbert, R. B., \& Barrey, R. K. (2006). Protestant approaches to death. overcoming death's sting. In: K. Garces-Foley (ed.), Death and religion in a changing world (pp. 122-146). New York: M. E. Sharpe.

Malinowski, B. (1925). Magic Science and Religion. In: J. Needham (ed.), Science, Religion and Reality (Pp. 19-84). New York: Macmillan.

Norenzayan \& Hansen. (2006). Belief in supernatural agents in the face of death. Personality and Social Psychology Bulletin, 32(2), 174-187.

Norenzayan, A., Dar-Nimrod, I., Hansen, I. G., \& Proulx, T. (2009). Mortality salience and religion: Divergent effects on the defense of cultural worldviews for the religious and the non-religious. European Journal of Social Psychology, 39(1), 101-113.

Pargament, K. I. (2002). Is religion nothing but...? Explaining religion versus explaning religion away. Psychological Inquiry, 13(3), 239-244.

Park, C. (2010). Making sense of the meaning literature: An integrative review of meaning making and its effects on adjustment to stressful life events. Psychological Bulletin, 136(2), 257-301.

Park. C. (2005). Religion and meaning. In R. P. \& C. Park (Eds.), Handbook of psychology of religion and spirituality (295-314). New York: Guilford Press.

Park, C. Cohen, L. H. \& Herb, L. (1990). Intrinsic religiousness and religious coping as life stress moderators for Catholics versus Protestants. Journal of Personality and Social Psychology, 59(3), 562-574.

Parkes, C. M. (1988). Bereavement as a psychosocial transition: Processes of adaptation to change. The Journal of social issues, 44(3), 53 -65.

Parkes, C. M. (1971). Psycho-social transitions: a field for study. Social Science and Medicine, 5 , 101-115.

Quartier, T. (2007). Bridging the gaps. An empirical study on Roman Catholic funeral rites. Münster: lit Verlag.

Spiegel, Y. (1973). Der Prozess der Trauer. Analyse und Beratung. München: Kaiser Verlag.

Storm, I. (2009). Halfway to heaven: Four types of fuzzy fidelity in Europe. Journal for the Scientific Study of Religion, 48(4), 702-718. 
Stroebe, M. S. (2004) Religion in coping with bereavement: confidence of convictions or scientific scrunity? The International Journal for the Psychology of Religion, 14(1), 23-36.

Tix, A. P., \& Frazier, P. A. (1998). The use of relgious coping during stressful life events: main effects, moderation, and mediation. Journal of Counseling and Clinical Psychlogy, 66(2), 411-422.

Tolstikova, K., Fleming, S., \& Charter, B. (2005). Grief, complicated grief, and trauma: the role of the search for meaning, impaired self-reference, and death anxiety. Illness, Crisis and Loss, 13(4), 293-313.

Turner, V. (2008: 1969). The ritual process. Structure and anti-structure. New Brunswick: Aldine Transaction.

Tylor, E. B. (1903: 1871). Primitive culture: Researches into the development of mythology, philosophy, religion, language, art, and custom. London: JohnMurray.

Unruh, D. R. (1983) Death and personal history: strategies of identity preservation. Social problems, 30(3), 340-351.

Verweij, J., Ester, P., \& Nauta, R. (1997). Secularization as an economic and cultural phenomenon: A cross-national analysis. Journal for the Scientific Study of Religion, 36 (2), 309-324.

Wojtkowiak, J., \& Venbrux, E. (2009). From soul to postself: home memorials in the Netherlands. Mortality, 14(2), 174-158. 